\title{
Reglementări canonice privind patrimoniul și misiunea
} Bisericii

\author{
Marius IOVAN*
}

Abstract: The notion of religious heritage, in the organization and functioning of the Romanian Orthodox Church, expresses all of the property belonging to parishes, hermitages, monasteries, deaneries, vicariates, bishops, archbishops, metropolitans and Patriarchate, associations and foundations established by the Church, and funds for a religious purpose, and church foundational wealth. The necessity of church property since the beginning of Christianity, for helping the poor, was a fundamental prerequisite for the life of the Church. By employing these goods shows that the Church uses to achieve its goal by using material resources. This means acquire a supernatural character by the application or their use, in accordance with the needs of the Church. Without material goods Church could not fulfill the role of aids to the needy, that could not capitalize Christian virtue of charity.

Keywords: canon, mission, heritage, church virtue.

\footnotetext{
* PhD Candidate, Faculty of Orthodox Theology at "Aurel Vlaicu" University in Arad, Romania.
} 


\section{Patrimoniul Bisericesc}

Actualul Statut pentru organizarea și funcționarea Bisericii Ortodoxe Române explică, în articolul 169, noțiunea de patrimoniu bisericesc astfel:

„Totalitatea bunurilor aparținand parohiilor, schiturilor, mănăstirilor, protopopiatelor, vicariatelor, episcopiilor, arhiepiscopiilor, mitropoliilor și Patriarhiei, asociațiilor și fundațiilor constituite de Biserică, fondurile destinate unui scop bisericesc, precum și averile bisericilor fundaționale, alcătuiesc patrimoniul bisericesc care aparține Bisericii Ortodoxe Romane, iar regimul lui este reglementat de prezentul Statut. Bunurile aflate în folosință fac de asemenea parte din patrimoniul bisericesc și se administrează conform actelor de dobândire și dispozițiilor prezentului Statut"’2.

Și în Biserica Romano Catolică este stipulat dreptul Bisericii de a deține bunuri materiale, prin care aceasta poate să-și atingă scopurile proprii, după cum rezultă din canonul 1254 din Codul de Drept Canonic al acestei Biserici:

„Prin drept înnăscut, în mod independent de puterea civilă, Biserica Catolică poate să dobândească, să posede, să administreze și să înstrăineze bunurile materiale, pentru a-şi atinge scopurile proprii. Principalele scopuri sunt: necesitatea de a organiza cultul divin, de a asigura întreținerea demnă a clerului și a altor slujitori și de a exercita opere de apostolat sacru și de caritate, mai ales față de săraci”’3.

În literatura teologică românească de specialitate, legată de studierea bunurilor bisericești, remarcăm, atenția deosebită pe care canonistul Iorgu D. Ivan o acordă cercetării canonice legate de bunurile ce alcătuiesc patrimoniul bisericesc ${ }^{4}$.

Acesta demonstrează necesitatea și dreptul Bisericii de a poseda averi sau bunuri, făcând trimitere la însăși noțiunea termenului de

${ }^{2}$ Statutul pentru organizare și funcționare al Bisericii Ortodoxe Române, București, Editura Institutului Biblic și de Misiune al Bisericii Ortodoxe Române, 2008, p. 98.

${ }^{3}$ Codul de Drept Canonic, text oficial și traducere în limba română, traducere de pr. Ioan Tămaș, Iași, Editura Sapienția, 2004, p. 729.

${ }^{4}$ Iorgu D. Ivan, Bunurile Bisericești în primele 6 secole. Situația lor juridică și canonică, București, Tipografia „Activitatea Grafică”, str. Bradului 33, 1937, p. 3. 
Biserică ${ }^{5}$, despre care afirmă că Mântuitorul i-a dat un dublu sens, acela al credinței creștine, prin care să se realizeze în omenire solidaritatea distrusă de înrăutățirea peste măsură a oamenilor, dar și de comunitate, formată din toți cei chemați de Dumnezeu la împărtășirea cu Fiul Său și care, prin ajutorul Sfintelor Taine, sunt aduși la mântuire de către urmașii în sfera de putere a apostolilor. Astfel, datorită acestei ultime calități a Bisericii, de comunitate de oameni pe pământ, aceasta se aseamănă într-o anumită măsură cu celelalte societăți omenești, definite de elemente precum: un număr de membrii, un scop către care să fie conduși membrii ei, o autoritate și anumite mijloace care să asigure îndeplinirea scopului ei ${ }^{6}$.

Totodată, Biserica se deosebește fundamental de celelalte societăți omenești prin faptul că acestea nu pot avea independență nelimitată în spațiu și în timp, așa cum Biserica are de la întemeietorul ei, care o pune în afara oricărui amestec din partea voinței omenești, când este vorba despre alegerea mijloacelor necesare mântuirii sufletului. Profesorul Iorgu Ivan mai arată că Biserica, fără a-și schimba caracterul acesta spiritual și fără a influența bazele ei stabilite de către Mântuitorul, datorită faptului ca aceasta lucrează pe pământ, pentru oameni și prin oameni, este nevoită să intre în legătură și cu lucrurile materiale ${ }^{7}$.

Această realitate a Bisericii de a intra în contact și de a deține bunuri materiale, despre care vorbește canonistul Iorgu D. Ivan, este reglementată și de către canoanele Bisericii Ortodoxe. În acest sens canonul 15 al Sinodului de la Ancira reglementează statutul juridic al

\footnotetext{
${ }^{5}$ Canonistul român Ioan N. Floca afirmă, legat de Biserică, faptul că aceasta este instituția care își duce acțiunea prin oameni și care a acționat întotdeauna ținând seama de ansamblul condițiilor în care trăiește omul, fiind ancorată în realitatea materială a vieții, deoarece omul, atât după natura sa materială cât și după cea duhovnicească, trăiește și lucrează în timp. Vezi: Ioan N. Floca, Canoanele Bisericii Ortodoxe Note și Comentarii, Ediția a III-a îmbunătățită, Sibiu, 2005, p. 279.

${ }^{6}$ Iorgu D. Ivan, op. cit., p. 1-2.

${ }^{7}$ Ibidem, p. 2.
} 
bunurilor Bisericii, stabilind că înstrăinarea acestora nu se poate face fără încuviințarea episcopului ${ }^{8}$.

Tot în această sferă a bunurilor bisericești se înscrie și canonul 38 apostolic, care prevede următoarele: „Episcopul să poarte grijă de toată averea bisericească și să o chivernisească, Dumnezeu fiindu-i supraveghetor, dar nu-i este lui iertat a-și însuși ceva din aceea sau a dărui rudelor sale cele ale lui Dumnezeu, iar de vor fi sărace să le dea ca unor săraci, însă să nu vândă sub acest cuvânt cele ce sunt ale Bisericii”" . Acest canon arată autoritatea deplină a episcopului în soluționarea problemelor bisericești, el având obligația de a purta grija bunurilor bisericești și dreptul de a le folosi în conformitate cu nevoile Bisericii. Din conținutul acestui canon mai reiese nu doar faptul că Biserica veche deținea bunuri sau averi, ci și modul de administrare al acestor bunuri și beneficiarii acestora. Astfel este cunoscut faptul că în Biserica veche averea Bisericii mai era numită și averea săracilor, deoarece alături de mântuirea sufletelor, grija de căpetenie a cârmuirii Bisericii era să alunge suferința celor lipsiții ${ }^{10}$.

Analizând situația bunurilor Bisericii din primele trei secole, canonistul Iorgu Ivan afirmă faptul că:

„Patrimoniul Bisericii, atât cât s-a putut agonisi la început, era administrat fără prea multe reguli de contabilitate, ci numai cu multă cinste, de către episcopi, căci tot clerul de care era nevoie pentru păstorirea sufletelor era grupat în jurul episcopului, la catedrala episcopală. Episcopul, în administrarea acestui patrimoniu, era ajutat de preoții și diaconii pe care îi avea la biserica catedrală"11.

Din cele prezentate reiese că Biserica deținea bunuri materiale chiar de la începutul ei. Originea acestui patrimoniu al Bisericii se

\footnotetext{
${ }^{8}$ Ioan N. Floca, Canoanele Bisericii Ortodoxe Note și Comentarii, Ediția a III-a îmbunătățită, Sibiu, 2005, p. 209.

${ }^{9}$ Nicodim Milaș, Canoanele Bisericii Ortodoxe, Vol. I, Partea I, Arad, Tipografia Diecezană, 1930, p. 246.

${ }^{10}$ Ioan N. Floca, op. cit., p. 31.

${ }^{11}$ Iorgu D. Ivan, op. cit., p. 134.
} 
găsea chiar în ofrandele pe care Mântuitorul Hristos le primea de la credincioși în timpul vieții sale pământești, toate constituind un bun comun ${ }^{12}$, din care se lua pentru trebuințele lui, ale apostolilor și pentru ajutorarea săracilor ${ }^{13}$.

\section{Legalitatea averii Biserici}

Necesitatea bunurilor bisericești, încă de la începuturile creștinismului, pentru ajutorarea săracilor este dovedită de faptul că Biserica folosește pentru atingerea scopului său mijloace materiale, care dobândesc un caracter supranatural prin aplicarea sau întrebuințarea lor. Astfel fără bunuri materiale Biserica nu și-ar putea împlini și rolul de ajutătoare a celor lipsiți, adică nu ar putea valorifica virtutea milei creștine ${ }^{14}$. Această rânduială a Bisericii este păstrată și afirmată și astăzi arătându-se că:

„Este în tradiţia Bisericii Ortodoxe ca să desfăşoare activităţi aducătoare de venituri pentru a susţine pe cei care nu se pot ajuta ei înşişi şi pentru a-şi împlini misiunea ei în societate. Apostolul Pavel îndemna pe fiecare credincios ,„s̆ se ostenească lucrând cu mâinile sale, lucrul cel bun, ca să aibă să dea şi celui ce are nevoie“ (Efeseni 4, 28), iar mănăstirile şi parohiile ortodoxe au o tradiţie seculară în a desfăşura activităţi gospodăreşti, nu doar pentru a-şi asigura traiul zilnic, ci şi cu scopul de a oferi un ajutor celui aflat în lipsuri materiale sau de a dezvolta activităţi misionar-culturale" ${ }^{\prime 15}$.

${ }^{12}$ Bunurile acestea comune sunt denumite de către profesorul Iorgu Ivan ,punga comună”, iar atunci când folosește acest termen, el face trimitere la două texte din Evanghelia după Ioan, unde este prezentată persoana lui Iuda Iscarioteanul, precum și situația acestor bunuri comune care erau în administrarea acestuia: „Dar el a zis aceasta nu pentru că îi era grijă de săraci, ci pentru că era fur și având punga, lua din ce se punea în ea”( Ioan 12,6). Și: „Căci unii socoteau, deoarece Iuda avea punga, că lui îi zicea Iisus: cumpără cele de care avem trebuință la praznic, sau să dea ceva săracilor". (Ioan 13, 29). Vezi: Iorgu D. Ivan, Op. cit., p. 38.

${ }^{13}$ Ibidem, p. 47.

${ }^{14}$ Ibidem, p. 4.

${ }^{15}$ Secretariatul Centrului Eparhial Iași, Ziarul Lumina, Ediția națională, joi 
Un alt aspect, referitor la folosirea patrimoniului bisericesc, este cel surprins prin reforma adusă cu privire la chivernisirea acestuia, de către Sfântul Ioan Gură de Aur, care separă patrimoniul săracilor de patrimoniul Bisericii cu care se confundase până atunci. Acțiunea luată de către Sfântul Ioan Gură de Aur, în acest sens, s-a impus ca o măsura juridică prin care se face distincție între bunurile instituției și cele ale persoanei ${ }^{16}$, instituția având astfel viața proprie independentă de personalitatea membrilor săi. Această măsură a fost preferată din considerente practice și prin ea s-a reușit scoaterea de sub bănuială a episcopului pentru întrebuințarea fondurilor bisericești $\mathrm{i}^{17}$.

Această formă, prin care Biserica a urmărit să răspundă nevoii de a fi un sprijin pentru cei săraci, nu a adus nici o modificare dreptului de proprietate. Dreptul de proprietate nu era influențat nici de faptul că, după îndemnul apostolilor, unii creștini își vindeau bunurile și banii obținuți erau puși în „punga comună”, chiar dacă aceste fapte se împlineau prin instituții speciale, înființate de către Biserică în acest scop ${ }^{18}$.

În epoca primară trebuie reținut faptul că:

„Proprietatea privată era constituită din toate bunurile imobile şi mobile ale unui cetăţean al Imperiului, socotindu-se ca un bun, proprietate privată chiar persoana sclavului. Mai mult, robii, având în vedere faptul că făceau parte din bunurile patrimoniale, erau supuşi impozitării pentru folosul serviciului adus. Se remarcă faptul că un cetăţean liber cât de sărac trebuia să se bucure de serviciul cel puţin al unui sclav"19.

14 iunie 2007, Conform: http://ziarullumina.ro/pastorala-de-craciun/bunurilebisericii-nu-imbogatesc-pe-nimeni-ci-ajuta-comunitatea, (accesssed October, 30,2014 , at 16:56).

${ }^{16} \mathrm{Cu}$ privire la aceste noțiuni a se vedea și: Roxana Topor, Fundația, persoană juridică, Teză de doctorat susținută la Facultatea de Drept, Universitatea de Vest, Timișoara, 2009, p. 30.

${ }^{17}$ Iorgu D. Ivan, op. cit., p. 6.

${ }^{18}$ Idem, Bunurile Bisericești în primele șase secole. Situația lor juridică și canonică, ediție îngrijită de Lect. Dr. George Grigoriță și drd. Daniel Grigore Filimon, București, Editura Basilica, 2014, p. 38.

${ }^{19}$ Constantin Voicu, Bunurile materiale în concepţia vasiliană, în Revista 
Tot cu privire la concepția despre proprietate în Biserica primară, se remarcă faptul că în creștinism nu numai că nu s-a disprețuit proprietatea individuală, ci s-a făcut din întrebuințarea ei o condiție imperativă pentru dobândirea mântuirii, precum și un mijloc de unitate între bogați și săraci, prin care să se ajungă la o armonie socială. Acest fapt disculpă Biserica de orice învinuire conform căreia aceasta ar fi acuzată că prin concepția ei despre proprietate, s-ar pune în primejdie ordinea socială. Această realitate este demonstrată de către profesorul Iorgu Ivan, prin citarea scriitorului Tertulian, care le spune păgânilor că banii ce pe ei îi separă, pe creștini îi unesc, deoarece creștinii, fiind toți o inimă și un suflet, nu ezită să-și pună pungile în comun ${ }^{20}$.

Aceste principii de unitate și sprijin între cei bogați și cei săraci se regăsesc și în scrierile Părinților Apostolici, unde, în Epistola către Diognet, se arată că: „Nu poți fi fericit, dacă împilezi pe aproapele tău, nici dacă vrei să fii mai presus decât cei slabi, nici dacă te îmbogățești și asuprești pe cei sărmani, nici nu poți imita pe Dumnezeu cu aceste fapte pentru că ele sunt străine măreției lui Dumnezeu"'21.

Referitor la opinia Părinților bisericești, legată de proprietatea individuală a creștinilor, se evidențiază și faptul că aceștia apără bunul săracului contra celui bogat care-l cotropește, precum și bunul bogatului, de dorința celui ce-și dorește să pună stăpânire peste el, subliniind și faptul că Sfinții Părinți au ținut de legitimă proprietatea și că niciodată nu au afirmat că renunțarea la proprietate este o datorie a tuturor creștinilor ${ }^{22}$.

Amintim în acest sens și concepția părintelui capadocian Vasile cel Mare, conform căreia din punct de vedere juridic, proprietatea este inviolabilă, iar in virtutea acestui fapt ea trebuie apărată cu orice

Teologică, nr. 4, anul 2009, p. 48.

${ }^{20}$ Prof. dr. Iorgu D. Ivan, op. cit., p. 40-41.

${ }^{21}$ Epistola către Diognet, Părinți și Scriitori Bisericești, vol. 1, Scrierile Părinților Apostolici, Traducere, note și indice de Pr. D Fecioru, București, Editura Institutului Biblic și de Misiune al Bisericii Ortodoxe Române, 1979, p. 344.

${ }^{22}$ Iorgu D. Ivan, op. cit., p. 40. 
preț, chiar în fața instanțelor de judecată civile, după cum se arată în scrisoarea adresată guvernatorului Candidian al Capadociei ${ }^{23}$.

Totodată, analizând aspecte din opera lui Lactanțiu, referitoare la statutul social al creștinilor din primele două secole, reiese că: „liberalitățile dintre creștini erau așa de abundente în primele două secole după întemeierea Bisericii de către Mântuitorul Iisus Hristos, încât se pare că între ei nu existau nici bogați nici săraci”’24. Această situație era posibilă datorită faptului că prin concepția creștină despre proprietate, exprimată de Ioan Gură de Aur, se înțelegea că orice bun nu era proprietatea creștinului ci era proprietatea lui Dumnezeu, prin care se ajutau cei nevoiași. Bogatul, fiind numai un administrator al bunurilor hotărâte pentru săraci, era dator să nu întrebuințeze pentru sine mai mult decât îi era de trebuință. Bunurile personale trebuiau cruțate, ca și cum nu ar fi o proprietate personală, ca tocmai prin această măsură, cel ce le deține să ajungă să se bucure în mod deplin de posesia $\operatorname{lor}^{25}$.

Atât canonistului Nicodim Milaș, cât și Iorgu Ivan susțin că dreptul Bisericii de a deține bunuri în posesie se datorează atât dreptului natural cât și dreptului divin ${ }^{26}$.

Dreptul natural este acceptat și descris în teologia ortodoxă ca fiind legat de natura rațională a omului, prin care acesta poate cunoaște legile și regulile fundamentale ale moralei și ale vieții sociale. Această lege își are sursa în voia lui Dumnezeu care 1-a creat pe om după chipul Său și după propria voie, și poate fi cunoscută prin experiență și rațiune, iar conținutul ei corespunde cu Decalogul Mozaic. Acesta fiind o legătură și un fundament pentru toate legile pozitive, laice sau bisericești, care-i sunt supuse și de la care-și obțin

\footnotetext{
${ }^{23}$ Constantin Voicu, op. cit., p. 49.

${ }^{24}$ Iorgu D. Ivan, op. cit, p. 40-41.

${ }^{25}$ Ioan Gură de Aur, Predici la Duminici și Sărbători, Traduse și orânduite de Melchisedec, Episcop de Roman, Ediția a II-a, Bacău, Editura Buna Vestire, 2005, p. 238-239.

${ }^{26}$ Iorgu D. Ivan, op. cit., p. 40.
} 
autoritatea $\operatorname{lor}^{27}$.

Aceste drepturi naturale ale omului trebuie să se regăsească și în Biserică, întrucât aceasta este formată din oameni. Iar dacă acestora li se admit aceste drepturi, cu atât mai mult se impune necesitatea unui patrimoniu temporal atunci când vorbim de Biserică, deoarece aceasta dispune de un caracter de perpetuitate, atribuit ei de către Mântuitorul Hristos, întemeietorul ei ${ }^{28}$.

Dreptul Bisericii asupra bunurilor temporale este stipulat și în Codul Canoanelor Bisericilor Orientale, emis de către Papa Ioan Paul al II-lea, în anul 1991, în care, conform canonului 1007, Biserica este descrisă ca având dreptul înnăscut de a dobândi, de a poseda, de a administra și de a înstrăina acele bunuri temporale care îi sunt necesare pentru scopurile sale ${ }^{29}$.

Aceste prescripții menționate mai sus nu sunt străine nici Bisericii primare, dacă ținem cont de faptul că Sfântului Vasile cel Mare a fost fondatorul Vasiliadei, ce s-a dovedit a fi o instituţie de îngrijire socială şi medicală. Aceasta era inclusă în patrimoniul Bisericii şi cuprindea case pentru cei lipsiţi, un corp de clădiri pentru străini şi chiar un spital pentru bolnavi ${ }^{30}$.

În concluzie, din analiza celor expuse, observăm faptul că Biserica, fără a-și schimba caracterul spiritual și fără a influența bazele ei stabilite de către Mântuitorul, este îndreptățită să posede un patrimoniu. Totodată din cele analizate reiese că, atât în Biserica primară cât și în Biserica Ortodoxă, precum și în Biserica Romano Catolică, este stipulat dreptul Bisericii de a deține bunuri materiale, prin care aceasta poate să-și atingă scopurile proprii.

\footnotetext{
${ }^{27}$ Stanley S. Harakas, The natural law teaching of the Eastern Orthodox Church, în ,Greek Orthodox Theological Review”, anul 9 (1963-1964), nr. 2, p. 215-216. ${ }^{28}$ Iorgu D. Ivan, op. cit., p. 42.

${ }^{29}$ Codul Canoanelor Bisericiilor Orientale, traducere și editare Pr. Drd. Iuliu Vasile Muntean, Editura Presa Universitară Clujană, 2001, p. 521.

${ }^{30}$ Arhid. Prof. Univ. Dr. Constantin Voicu, op. cit., p. 50-51.
} 


\section{Bibliografie:}

1. *** Codul Canoanelor Bisericiilor Orientale, Traducere și editare Pr. Drd. Iuliu Vasile Muntean, Editura Presa Universitară Clujană, 2001.

2. *** Codul de Drept Canonic text oficial și traducere în limba română, traducere de pr. Ioan Tămaș, Iași, Editura Sapienția, 2004.

3. *** Epistola către Diognet, Părinți și Scriitori Bisericești, vol. 1, Scrierile Părinților Apostolici, Traducere, note și indice de Pr. D Fecioru, București, Editura Institutului Biblic și de Misiune al Bisericii Ortodoxe Române, 1979.

4. *** Statutul pentru organizare și funcționare al Bisericii Ortodoxe Române, București, Editura Institutului Biblic și de Misiune al Bisericii Ortodoxe Române, 2008.

5. Floca, Ioan N., Canoanele Bisericii Ortodoxe, Note și Comentarii, Ediția a III-a îmbunătățită, Sibiu, 2005.

6. Harakas, Stanley S., The natural law teaching of the Eastern Orthodox Church, în „Greek Orthodox Theological Review”, anul 9 (1963-1964), nr. 2, p. 215-230.

7. Ioan Gură de Aur, Predici la Duminici și Sărbători, Traduse și orânduite de Melchisedec, Episcop de Roman, Ediția a II-a, Bacău, Editura Buna Vestire, 2005.

8. Ivan, Iorgu D., Bunurile Bisericești in primele 6 secole. Situația lor juridică și canonică, București,Tipografia „Activitatea Grafică”, str. Bradului 33, 1937.

9. Milaș, Nicodim, Canoanele Bisericii Ortodoxe, Vol. I, Partea I, Arad, Tipografia Diecezană, 1930.

10. Topor, Roxana, Fundația, persoană juridică, Teză de doctorat susținută la Facultatea de Drept, Universitatea de Vest, Timișoara, 2009.

11. Voicu, Constantin, Bunurile materiale în concepţia vasiliană, în „Revista Teologică”, nr. 4, anul 2009.

\section{Web sources:}

1. http://ziarullumina.ro/pastorala-de-craciun/bunurile-bisericii nuimbogatesc-pe-nimeni-ci-ajuta-comunitatea, (accessed October 30, 2014 , at 16:56). 